\title{
The Study of the Cultivation and Development Strategy of English Teachers during the Local Universities' Transition Period
}

\author{
Guobo Jiang \\ Foreign Language Department , Ankang University, Ankang 725000, China
}

Keywords: Local universities, Transition period, English teacher, Cultivation, Development strategy

\begin{abstract}
The constant change and transformation of society is bound to trigger the reform in many aspects. The education system is also in a continuous reform and gradually begins the transition in which many vocational colleges merge and upgrade, which marks that the colleges in our country have formally entered the transition period. Local universities have always been the major force to train the teachers, so the quality of the education in local universities is largely influencing the development of the whole educational business. The transition of teacher education influences educational goals, school-running orientation and talent cultivation of the local universities. This article mainly studies the cultivation and development of English teachers during the transition period of the local universities.

Whether the English teachers can survive is largely related to the transition. Then how to cultivate their quality and ability, enhance the development of the industry become the main problems of English education. Along with the development of economic globalization, there is an increasing need of versatile English personnel. Universities, as the cradle of talent cultivation, have higher requirements of the English teachers' qualification and professional skills. How to cultivate and develop the teachers who are the major force in education is fundamentally important. Local universities are the core force of education transition, so how to cultivate the English teachers during the transition period of the universities is especially important. Strengthening teaching skills and professional level of the English teachers is conducive to the long and sustainable development of the education business in our country.
\end{abstract}

\section{The Existing Problems in the Cultivation and Development of English Teachers during the}

\section{Local Universities 'Transition Period}

(1). Local Universities’ Indifference toward English Teaching

Professor Dai from Beijing University thinks that in our country, English is at the edge of whole system in a university's discipline in most universities, which makes it lie in an obvious weak position. That also makes the teachers who are engaged in English teaching and study English tasks fall into an embarrassing situation, which has a great influence on the teaching research and extension of English. Local universities attach less and less importance to English so that it has dropped into the edge, which affects the teaching result of university English seriously. At the same time, English education in local universities is questioned unprecedentedly and faces serious challenges. English courses in local universities are considered as hollow courses without connotation. English is just another language. This attitude and idea is the main reason that the English education in local universities is time-consuming but only gains low teaching efficiency. The most important external course which influences the English teachers' professional development and identity depends on the subject attribute. English education in our country has drawn criticism from NPC delegates and CPPCC members. The general ignorance about university English education will certainly influence the effect the English teaching in local universities and then affects the career paths of the English teachers in local universities.

(2). English Teachers in Local Universities with High Pressure and Low Satisfaction

The salary of teachers in local universities is low and it also influences the treatment of university English teachers. Therefore, they have huge life pressure and at the same time, it lowers people's satisfaction about teaching profession. However, as the school's enrollment plan increases year by year, scale expands gradually and the number of students increases continuously, there is a 
shortage of English teachers, which leads to the big workload, more courses, increasing daily teaching time of the teachers. It increases English teachers' teaching time in class as well as the guidance outside the class, which brings them unprecedented working pressure. Being engaged in English teaching means to undertake a single and boring course and complete the teaching tasks repetitively. So as time passes, their passion for work vanishes gradually and they lose the interest in teaching and are tired of the teaching. In some universities, the English teachers do not have enough experiences of theoretical direction and their teaching methods are conservative and single, so they are handicapped in classroom teaching. The lack of sense of achievement in teaching and all sorts of negative factors bring down the career satisfaction of English teachers in local universities. This is adverse to the career development of the teachers.

(3)Backward Teaching Ideas and Concept of English Teachers in Local Universities.

If the conservative and single teaching mode, weak education consciousness of the teachers at present constitute a big challenge toward the improvement of education quality, then it is a deadly threat to English teaching, because the goal of English teaching idea and mode, unlike other disciplines, is not to impart professional knowledge, but to train students to apply what they have learned. The purpose of application ability is to allow the students have a lot of English practices in and outside the class and foster their ability of independent learning. Some inexperienced and young teachers are still using 'grammar-translation method' in class. Even though these teachers know that the modern and advanced teaching method is the 'communicative approach', teachers and students still think that grammar-translation method is more suitable to the reality due to many reasons. In this way, the class turns into a 'standup class' in which only the teacher speaks. The time for students to practice has been deprived, so they only have the opportunity of listening instead of speaking and practicing. Thus this teaching method cannot cultivate the application ability of the students.

(4).The Weak Research Consciousness and Spirit of English Teachers in Local Universities.

Most English teachers have weak research consciousness, lack research spirit and have little interest in scientific research. For most English teachers, they conduct the scientific research because they want to get a raise in their salary or gain professional titles. On the contrary, making scientific research due to the increase of comprehensive quality including teaching quality, professional skill and personal teaching cannot become the pursuit of most teachers. Since being an English teacher means to shoulder heavy and long teaching task, the teachers do not have much time for scientific research. Especially when the schools increase the enrollment, the phenomenon gets more serious. Many teachers feel exhausted by dealing with the teaching, so they do not have much free time. It is even hard for them to think and study the problems in teaching, let alone deepening the student-centered reform of education.

\section{The Strategy of the Solution to the Cultivation and Development Problems of English Teachers in Local Universities}

(1). Carrying out School-based Training Reasonably

The teaching level and ability of English teachers in local universities, which are closely related to the school's capacity for scientific research, affects the development of the students, the deepening and implementation of fundamental reform of English education. For some postgraduates who are directly recruited, they contact the teaching tasks immediately after they take office without the experience of being teaching assistant, thus they cannot gain the experience in practice. There are also many teachers who do not graduate from normal schools. They belong to the young teachers who haven't received the professional training. Therefore, carrying out the school-based training is very important. In recent years, the launch of school-based training has gained some achievements and it should be implemented in local universities to promote the development of them. Local universities should build a long-term training system for teachers, establish a three-level training system including teaching, school and college and perfect the school-based atmosphere of teacher development which is based on teaching and research and leaded by the school with the English institutes being the major part. Through reasonable school-based training, 
teachers can find their role quickly and become the model of others, and also teachers' influence on students can be exerted to a greatest extent.

(2).The Strategy of Apprenticeship

Implementing the teaching mode of apprenticeship embodies the interpersonal interaction theory in teacher cooperative culture. Many specialists find out through investigation that teaching is a very isolated industry. The comparably isolated mode is no use to the teacher extension and teaching exploration especially to those new teachers who just go into the workplace. It means that teachers need to explore in enclosed environment or stick to the status quo, but these bring no assistance to the teachers' teaching and go against the development and reform of education. Although teaching can be conducted in isolated situation alone, cultural sharing is bound to be proceeded if the teachers want to develop continuously in professional field. The teaching method of apprenticeship is the constant cooperation of senior teachers and new teachers. New teachers observe and imitate the teaching of the senior teachers, complete the teaching under the guidance of senior teachers and gradually experience the potential experience and grasp the professional teaching and cultivation method. These potential experience and educational knowledge cannot be expressed by language, but they can be passed through experiment and practice to some extent. Therefore, the wisdom and experience can be passed on by the mode of apprenticeship. However, this teaching method should be established on the fundamental objective that both sides teach together willingly, otherwise, it exists in name only and has no meaning.

(3).The Multi-directional Development of the English Teachers Themselves

1. Establishing the Sense of Scientific Research

For a long time, there exists academic and educational argument inside the local universities. In fact, English teachers in local universities should set up exemplary consciousness, introspection and normal consciousness as well as the consciousness of scientific research. When the new teachers take office, they can promote the development of research consciousness which can also facilitate teaching under the teaching mode of apprenticeship. The method of letting the colleagues attend the class such as collaborative lesson-planning, open class in English teaching and research group can stimulate their thinking and promote the research work of the teachers to a largest extent. It can also help teachers experience the teaching better, form a unique perception, which accordingly causes the appearance of rational research. The development of the newly appointed English teachers in local universities cannot do without the research and studies of themselves. They can gain the resources through some English books and English periodicals, or they can conduct case studies toward the students in order to lay a foundation for the future scientific research and topics declaration so as to reduce their time of becoming a professional teacher to a largest extent. The progress of teachers dates back to the development of the students and at the same time, the development of teachers also provides protection for the advancement of the students, which accords with the theory that teaching benefits teachers as well as students

\section{Establishing the Introspection Consciousness}

The cultivation and development of English teachers in local universities is mainly the improvement of professional level, especially the practical knowledge in teaching. They should conduct introspection constantly. English teachers should reflect themselves before, in and after the class. Firstly, English teachers should rethink the teaching plan compilation and teaching design before the class. The introspection about the teaching design is an aforehand plan aiming at the teaching flow made by the teachers who conducts unceasing conclusions about teaching contents and objects according to teaching theory and curriculum requirements and it also reveals English teachers' teaching art and procedures. The important part of teaching compilation is the exploration about teaching contents. Secondly, the main factor of English teachers in class is the reflection in the class. In real class, there are always some unexpected events, then the teachers need to take introspection to figure out the problems so as to take some measures. Thirdly, the introspection after class mainly contains teaching notes and after-class thoughts. Teaching notes is the reminder for the teachers so that they can change their teaching method and strategy continuously. In this way, similar situations can be avoided in the future and also the teaching efficiency can be improved. 
After-class thoughts actually mean that the teachers conduct self-evaluation, draw lessons from experience and sum up the experience to improve their teaching standard.

\section{Establishing Normal Consciousness}

English teachers in local universities shoulder heavy responsibilities and undertake the significant duty of talent cultivation. Their values, outlook on life, teaching views, teaching method and attitude influence the students in local universities in some way. English teachers in local universities should first possess a certain idea of English education, which plays a vital role in the talent cultivation. The teaching principle of the English teachers in local universities can restrict their teaching behavior or even influence the professional knowledge of the English teachers. Therefore, a scientific teaching principle has a guiding effect on the professional development of English teachers. The development of English teachers in local universities, which is closely related to the internal development and quality of teachers, is the momentum and consciousness of development. Therefore, English teachers need to have reflection, conduct independent study constantly in order to reach the goal of surmounting themselves and realize overall development. They should be guided by their own development, keep proceeding the reflection of teaching method and behavior, continuously observe themselves to see whether it conforms to the teaching requirements, and update their teaching ideas constantly so as to change their teaching methods. The development momentum of English teachers is the continuous introspection and the pursuit of higher values.

\section{Establishing Exemplary Consciousness}

The local universities are gradually becoming the main places for the cultivation of English teachers. Along with the constant reform of educational system, English teachers are not only the designer of the class, but also the instructor and assistor. But due to the severe lack of English teachers in local universities, many newly appointed English teachers gradually undertake the teaching work, which provides these new teachers a growth platform. Therefore, English teachers should develop their own teaching methods and ideas and improve their teaching skills in the shortest time in order to become a teacher with demonstration effect. In this way, the students can build the idea in which the teachers play the leading role and students are the core in the process of learning. They can also overcome all the difficulties to a largest extent and lay emphasis on the interaction among the teachers and students. Then a teaching system can be set up and teachers and students can form the ability of communication through eye-contact. The blackboard-writing can be used to present the contents and goal of the class. Teachers must act with strong logic and fluent language, conduct the

\section{Conclusion}

In total, the cultivation of English teachers in local universities is a long task. Along with the development of the society, English is becoming more and more international, so the cultivation of English teachers in local universities is very important. So we should find out the problems existing in teaching process reasonably, put forward the solutions, promote the industry development of English teachers, improve teaching skills and adjust to the reform of education gradually.

\section{References}

[1] Wei Xiaoze, Yaojing. The Investigation of the Rationality of the English Major's Course Installation in Local Normal Universities[J]. Journal of Kiamusze Education Institute, 2014(6):219-220,222.

[2] Ye Zizi, Li Haixia. The Strategy Analysis of Teacher Cultivation under the Teaching Reform System Integration of Public and Industry English in Vocational Colleges[J] Overseas English(Volume 1) ,2012(7):361-362. 
[3] Leng Zhinan.The Construction of Evaluation System of the Cultivation and Self-development of English Teachers in Vocational Colleges[J].Journal of Jiangxi Electrical Power Vocational and Technical Institute, 2014,27(2):41-43.

[4] Xu Benwei. The Study of the Career Identity of the Free Normal Students Majoring in English under Individual Perspective of Knowledge-Taking Xinan University as an Example[D]. Xinan University,2011.

[5] Zhe Hongjun, Caoning, Lijun,etc The Rights and Responsibilities Prescribed by statues, the Breakdown of Strong Force with Joint Forces-The Study Report of the Reform of the Pre-service Cultivation Mode of English Teachers[J].Journal of Longdong Institute, 2012,23(4):128-132. 